\title{
Application of wood chips for soil mulching in the cultivation of ornamental grasses
}

\author{
Monika Henschke ${ }^{1 *}$, Barbara Politycka ${ }^{2}$ \\ ${ }^{1}$ Department of Ornamental Plants \\ Poznań University of Life Sciences \\ Dąbrowskiego 159, 60-594 Poznań, Poland \\ ${ }^{2}$ Department of Plant Physiology \\ Poznań University of Life Sciences \\ Wołyńska 35, 60-637 Poznań, Poland
}

\begin{abstract}
A mulch is a layer of material applied to the surface of the soil. Mulching plays an important role in the maintenance of green spaces. Organic materials are still sought for the preparation of mulches. Recently interest in wood chips has grown. The aim of the study was to determine the effect of mulching with pine and birch chips on the contents of phenolic compounds in the soil, as well as on the growth and flowering of ornamental grasses - Bouteloua gracilis (Kunth.) Lag. ex Griffiths, Panicum virgatum L. and Pennisetum alopecuroides L. The content of phenolic compounds in the soil steadily increased from spring to autumn. Mulching led to a substantial increase in the level of phenolic compounds. In the first year of cultivation more phenolic compounds were released by chips of pine than birch, while in the second year this difference did not occur. Mulching had a negative impact on the growth and flowering of ornamental grasses, especially in the first year of cultivation. Ornamental grass sensitivity to the substances released from mulches decreased with the age of the plants and was dependent on the species - Bouteloua gracilis was found to be particularly sensitive.
\end{abstract}

Key words: birch chips, perennials, phenolic compounds, pine chips, Poaceae, soil covering

\section{INTRODUCTION}

Mulching is a popular form of soil care in green areas. It limits weeding, reduces evaporation and stabilizes soil temperatures which indirectly contributes to better plant growth. For this purpose various organic materials are used, for example pine bark (Henschke and Jerzy 2006, Henschke et al. 2008). In recent years, interest has grown in mulches from a variety of wood wastes, which are crushed and coloured. Wood chips are durable and easy to use as an organic material for mulching. Their sources are sawmill wastes and wastes arising from logging or cutting trees and shrubs (Duryea 2000). Sometimes processed wood is also utilized, for example pallets, wooden constructions, etc. (Herms et al. 2002). Most commonly, the branches of various tree species are used, fresh and without composting. Wood waste composting is a time- and cost-consuming process, due to the high $\mathrm{C} / \mathrm{N}$ ratio, which for pine wood is about 1500, and 700 for birch wood (Bantle et al. 2014). Thus, the use of wood wastes for the production of mulches is a simple way of disposal. However, although the wood chips are easy to obtain and one

\footnotetext{
*Corresponding author. 
of the cheapest organic materials for mulching, especially in green areas, their application may be associated with the release of substances toxic for plants into the soil. The biological activity of phytotoxic substances depends on their chemical nature and the tree species from which they are derived (Rathinasabapathi et al. 2005). It has been noted that strongly lignified wood wastes decomposed in the soil by micro-organisms are a source of phenolic compounds, even small amounts of which may adversely affect the growth and development of plants (Reigosa and Pedrol 2002, Bantle et al. 2014).

Ornamental grasses are becoming a more highly valued group of plants used in green areas. These plants have the distinguishing characteristics of long, streamlined leaves, delicate inflorescences and soft colours that distinguish them against the background of other perennials. In addition, the grasses tolerate adverse habitat conditions well, and their wide diversity allows the relevant species to be matched to various positions (Henschke 2013, 2014).

In order to evaluate the usefulness of pine and birch chips for soil surface mulching in the cultivation of ornamental grasses, the content of phenolic compounds in the soil and the growth and flowering indices of plants were determined.

\section{MATERIAL AND METHODS}

The objects of study were the species of grasses Bouteloua gracilis (Kunth.) Lag. ex Griffiths, Panicum virgatum L. and Pennisetum alopecuroides L. and soil mulched with chips from the wood of pine (Pinus sylvestris L.) or birch (Betula pendula L.) and non-mulched soil (control). The plants were planted into the ground in autumn 2008 on the area of the plant collection of the University of Life Sciences in Poznań, and their growth and blooming were observed for three successive growing seasons until September 2011. The soil for plant cultivation was light sandy loam of $\mathrm{pH} 7.0-7.3$, quite rich in nutrients. During the study each year in the first decade of April soil samples for chemical analyses were collected. Based on results of analyses recommendations were developed and fertilization was applied to provide nutrient contents in the soil consistent with values within the following limits $\left(\mathrm{mg} \mathrm{dm}^{-3}\right)$ : 70-150 N-NO, $80-150$ P, 200-350 K, 115$170 \mathrm{Mg}$. Plants obtained from the seeds were grown in pots from the spring of 2008. At the beginning of the experiment Bouteloua gracilis have 23 blades, Panicum virgatum have 9 blades and Pennisetum alopecuroides have 12 blades. Each species was planted on three plots, each with an area of $9 \mathrm{~m}^{2}$, which constituted a replication. Each plot was divided into three strips of $3 \mathrm{~m}^{2}$; in the first strip the surface of the soil was non-mulched (control), in the second and the third ones it was mulched with pine chips and with birch chips respectively. $B$. gracilis was planted at a density of 4 plants per $\mathrm{m}^{2}$, and $P$. virgatum and $P$. alopecuroides at a density of 2 plants per $\mathrm{m}^{2}$. Chips applied to mulching were made on the need for experience obtained from branches crushed to the fraction $1-3 \mathrm{~cm}$. Fresh wastes, without previous composting, were spilled on the surface of the soil in the spring of 2009 to form a cover with a thickness of 5-6 cm. The loss of mulch was supplemented with fresh chips to the same level in spring 2010 and 2011. The content of phenolic compounds in the soil layer $0-10 \mathrm{~cm}$ was determined on 1 May, 15 July, and 1 October, 2009 and 2010. Representative samples were taken from each combination, and the analysis were carried out in three replications. Phenolic compounds from the soil were extracted in $80 \%$ ethanol according to Politycka and WójcikWojtkowiak (1984). The total content of phenolic compounds was determined spectrophotometrically (UV-VIS spectrophotometer Jasco V-530) using the Folin-Ciocalteu reagent (Singleton et al. 1999). The results were expressed in micrograms per gram of dry matter of soil using $p$-coumaric acid as a standard. The dry mass of soil was determined by the common dryer method. Measurement of plant growth indices was carried out in October 2009, 2010 and 2011. The height of plants (at the flowering stage from the base to the top of clumps), length of flag leaf, and the percentage of coverage of the soil surface by leaf blades (using a truss with dimensions of $1 \times 1 \mathrm{~m}$, divided into 100 squares) were measured. We also recorded the onset of flowering date (first inflorescence on the plant), and during the full flowering the number of inflorescence culms and their length from the base of plant to the end of the inflorescence were measured. Analysis of phenolic compounds contents in the soil covered nine combinations (mulching $\times$ sampling time) within each species. In each combination there were three replications, for each of the twelve plants of $B$. gracilis, and for the six plants of $P$. virgatum and P. alopecuroides. Observations of plant growth and flowering included three variants of the mulching (non-mulched control, mulched with pine chips and mulched with birch chips) within each species. Within the framework of each variant there were 
three replications, each of the twelve plants of $B$. gracilis and for the six plants of $P$. virgatum and $P$. alopecuroides. A statistical assessment of the content of phenolic compounds in the soil was performed by two-way analysis of variance, and an assessment of the indices of growth and flowering of plants by one-way analysis of variance, both using the Newman-Keuls test, at a level of significance $p=0.05$.

\section{RESULTS AND DISCUSSION}

The use of wood chips for soil mulching contributed to an increase in the content of phenolic compounds in its upper layer (Tab. 1). Regardless of the mulching and grass species, the level of phenols increased from spring to autumn. In the first year of mulching, more phenols were found in soil mulched with pine chips than with birch chips. In the second year, the content of phenols was the same using both types of wood chips. In 2009, in the cultivation of $B$. gracilis we found that in the non-mulched soil the content of phenolic compounds was the lowest, while higher content was found in the soil mulched with birch chips, and the highest was found in soil mulched with pine chips. At the beginning of the growing season (1 May) the level of phenolic compounds was the lowest (1.0-1.5 $\mu \mathrm{g} \mathrm{g}^{-1}$ d.w.). At this time, in alternatively mulched soil the content of phenolic compounds was no different from that of the control, but at subsequent times it was higher in the mulched soil then in the non-mulched soil. In October, the level was 4-6 times higher than in May. At this time the highest level of phenolic compounds was found in the soil mulched with pine chips $\left(6.7 \mu \mathrm{g} \mathrm{g}^{-1}\right.$ d.w.). A similar relationship was found in the cultivation of $P$. virgatum, but already in May by half higher content of phenolic compounds in the mulched soils than in the control was observed. In the cultivation of P. alopecuroides in May more phenolic compounds then in the control (by half) were observed in the soil mulched with birch chips. At subsequent times the content of phenolic compounds was higher. In October, there were 1.5-4 times higher levels than in May. At this time the highest level of phenolic compounds was in the soil mulched with pine chips $\left(5.8 \mu \mathrm{g} \mathrm{g}^{-1}\right.$ d.w.). In 2010 in the cultivation of $B$. gracilis, it was demonstrated that, like in 2009 in non-mulched soil, there was a lower level of phenolic compounds than in mulched soil, but the differences occurred at the beginning of the growing season (May and July). We also observed differences in the content of phenolic compounds at different times, but only in the non-mulched soil. In the first two times the content of phenolic compounds was similar $(3.3 \mu \mathrm{g}$ $\mathrm{g}^{-1}$ d.w.), while it was higher in October $\left(4.3 \mu \mathrm{g} \mathrm{g}^{-1}\right.$ d.w.). The content of phenolic compounds in the mulched soil with both types of wood chips was similar throughout the growing season and was in the range of 4.5-5.7 $\mu \mathrm{g} \mathrm{g}^{-1}$ d.w. The dependencies were slightly different in the other two species, which are characterized by a larger size and a greater extent of soil coverage with the leaf blades during vegetation. The mulched soil under

Table 1. The effect of mulching with pine and birch chips on the content of phenolic compounds in the soil ( $\mu \mathrm{g} \mathrm{g}^{-1} \mathrm{~d}$.w.)

\begin{tabular}{|c|c|c|c|c|c|c|c|c|c|}
\hline \multirow[t]{2}{*}{ Species } & \multirow[t]{2}{*}{$\begin{array}{l}\text { Sampling } \\
\text { time }\end{array}$} & $\begin{array}{l}\text { Without } \\
\text { mulching }\end{array}$ & $\begin{array}{l}\text { Mulching } \\
\text { with pine } \\
\text { chips }\end{array}$ & $\begin{array}{l}\text { Mulching } \\
\text { with birch } \\
\text { chips }\end{array}$ & Mean & $\begin{array}{l}\text { Without } \\
\text { mulching }\end{array}$ & $\begin{array}{l}\text { Mulching } \\
\text { with pine } \\
\text { chips }\end{array}$ & $\begin{array}{l}\text { Mulching } \\
\text { with birch } \\
\text { chips }\end{array}$ & Mean \\
\hline & & \multicolumn{4}{|c|}{2009} & \multicolumn{4}{|c|}{2010} \\
\hline \multirow{4}{*}{$\begin{array}{l}\text { Bouteloua } \\
\text { gracilis }\end{array}$} & May $1^{\text {st }}$ & $1.0 \mathrm{a}^{*}$ & $1.1 \mathrm{a}$ & $1.5 \mathrm{a}$ & $1.2 \mathrm{a}$ & $3.3 \mathrm{a}$ & $5.6 \mathrm{c}$ & $4.5 \mathrm{bc}$ & $4.5 \mathrm{a}$ \\
\hline & July $15^{\text {th }}$ & $2.7 \mathrm{~b}$ & $4.6 \mathrm{c}$ & $4.6 \mathrm{c}$ & $4.0 \mathrm{~b}$ & $3.3 \mathrm{a}$ & $5.4 \mathrm{bc}$ & $4.8 \mathrm{bc}$ & $4.5 \mathrm{a}$ \\
\hline & October $1^{\text {st }}$ & $4.5 \mathrm{c}$ & $6.7 \mathrm{e}$ & $5.4 \mathrm{~d}$ & $5.5 \mathrm{c}$ & $4.3 \mathrm{~b}$ & $5.2 \mathrm{bc}$ & $5.7 \mathrm{c}$ & $5.0 \mathrm{~b}$ \\
\hline & Mean & $2.8 \mathrm{a}$ & $4.2 \mathrm{c}$ & $3.8 \mathrm{~b}$ & & $3.6 \mathrm{a}$ & $5.4 \mathrm{~b}$ & $5.0 \mathrm{~b}$ & \\
\hline \multirow{4}{*}{$\begin{array}{l}\text { Panicum } \\
\text { virgatum }\end{array}$} & May $1^{\text {st }}$ & $1.4 \mathrm{a}$ & $2.3 \mathrm{~b}$ & $2.0 \mathrm{~b}$ & $1.9 \mathrm{a}$ & $3.7 \mathrm{a}$ & $3.8 \mathrm{a}$ & $4.2 \mathrm{~b}$ & $3.9 \mathrm{a}$ \\
\hline & July $15^{\text {th }}$ & $2.3 \mathrm{~b}$ & $3.9 \mathrm{~d}$ & $3.4 \mathrm{c}$ & $3.2 \mathrm{~b}$ & $3.7 \mathrm{a}$ & $4.4 \mathrm{~b}$ & $4.5 \mathrm{~b}$ & $4.2 \mathrm{~b}$ \\
\hline & October $1^{\text {st }}$ & $4.6 \mathrm{e}$ & $5.8 \mathrm{f}$ & $5.0 \mathrm{e}$ & $5.1 \mathrm{c}$ & $3.9 \mathrm{a}$ & $5.1 \mathrm{c}$ & $5.1 \mathrm{c}$ & $4.7 \mathrm{c}$ \\
\hline & Mean & $2.8 \mathrm{a}$ & $4.0 \mathrm{c}$ & $3.5 \mathrm{~b}$ & & $3.8 \mathrm{a}$ & $4.5 \mathrm{~b}$ & $4.6 \mathrm{~b}$ & \\
\hline \multirow{4}{*}{$\begin{array}{l}\text { Pennisetum } \\
\text { alopecuroides }\end{array}$} & May $1^{\text {st }}$ & $1.2 \mathrm{a}$ & $1.4 \mathrm{a}$ & $1.9 \mathrm{~b}$ & $1.5 \mathrm{a}$ & $3.9 \mathrm{a}$ & $4.2 \mathrm{a}$ & $4.0 \mathrm{a}$ & $4.0 \mathrm{a}$ \\
\hline & July $15^{\text {th }}$ & $3.9 \mathrm{c}$ & $4.2 \mathrm{~cd}$ & $3.9 \mathrm{c}$ & $4.0 \mathrm{~b}$ & $3.9 \mathrm{a}$ & $4.5 \mathrm{ab}$ & $4.1 \mathrm{a}$ & $4.2 \mathrm{a}$ \\
\hline & October $1^{\text {st }}$ & $3.9 \mathrm{c}$ & $5.8 \mathrm{e}$ & $4.6 \mathrm{~d}$ & $4.8 \mathrm{c}$ & $5.1 \mathrm{bc}$ & $5.5 \mathrm{c}$ & $5.6 \mathrm{c}$ & $5.4 b$ \\
\hline & Mean & $3.0 \mathrm{a}$ & $3.8 \mathrm{c}$ & $3.5 \mathrm{~b}$ & & $4.3 \mathrm{a}$ & $4.8 \mathrm{~b}$ & $4.6 \mathrm{ab}$ & \\
\hline
\end{tabular}

*Values for species marked with the same letters do not differ significantly at $p=0.05$ 
$P$. virgatum contained more phenolic compounds than the control (excluding May, when more phenolic compounds then in the control were observed only in the soil mulched with birch chips). In the period from spring to autumn the level of phenolic compounds was stable in the non-mulched soil, while their content significantly increased from 3.7-3.9 $\mu \mathrm{g} \mathrm{g}^{-1}$ d.w. to $5.1 \mu \mathrm{g} \mathrm{g}^{-1}$ d.w. in the soil mulched with pine chips, and it increased in October to the level of $5.1 \mu \mathrm{g} \mathrm{g}^{-1}$ d.w. in the soil mulched with birch chips. In the cultivation of $P$. alopecuroides we found that only the soil mulched with pine chips had more phenolic compounds than the non-mulched soil. An increase in the level of phenols in non-mulched and mulched soil was found only in October.

The content of phenolic compounds in the soil increased from spring to autumn, to a greater extent in the mulched than in the non-mulched soil. This suggests the release of phenolic compounds to the soil both from mulches and from plants. The secretion of phenolic compounds to the soil by the roots of plants of the family Poaceae is well documented in the literature (Sánchez-Moreiraz et al. 2015). There is a lack of references on the accumulation of phytotoxic substances in the soil under horticultural organic mulches, but it is known that such substances are secreted by the wood residues. The results obtained by Rathinasabapathi et al. (2005) showed the phytotoxic activity of wood chips from deciduous trees and conifers (Acer rubrum, Quercus michauxii, Juniperus silicicora,
Azadirachta indica, Magnolia grandiflora). Wood chips of these species added to substrate restricted growth of Desmodium tortuosum in a greenhouse experiment. In this study the effects of wood chips of Pinus taeda were also examined, but they did not have such adverse effects as the chips of the above-mentioned species of trees. Applying mulches of wood chips showed a significant impact on the growth of ornamental grasses (Tab. 2). In the cultivation of $B$. gracilis the mulched plants were shorter than the non-mulched ones by $6.8-7.5 \mathrm{~cm}$ in 2009. The same relationship was also observed in 2010 (by 10.6-17.8 cm) and 2011 (by 5.6-6.9 cm). In the first year of cultivation birch chips had a more adverse effect on growth than pine chips, which was reflected by the fact that the plants mulched with them had shorter flag leaves and covered the surface of the soil to a lesser extent. The flag leaves of plants mulched with birch chips were shorter than the rest, $2.6-3.3 \mathrm{~cm}$, and coverage of the soil by these plants was less by 12.5 percentage points than non-mulched plants and by 8 percentage points than plants mulched with pine chips. The effect on the growth inhibition of flag leaves was also observed during the second year of cultivation. The growth of $P$. virgatum also depended on soil mulching, but most of all in the first year of cultivation. The adverse effects of mulch from birch wood were demonstrated. Plants mulched with it were shorter by $16 \mathrm{~cm}$, had shorter flag leaves and covered the soil by $2.4 \mathrm{~cm}$ and by 18.5 percentage points lesser extent than non-mulched plants. In the second year

Table 2. The effect of mulching with pine and birch chips on the growth of ornamental grasses

\begin{tabular}{|c|c|c|c|c|c|c|c|c|c|}
\hline \multirow[b]{2}{*}{ Year } & \multicolumn{3}{|c|}{ Height of plant $(\mathrm{cm})$} & \multicolumn{3}{|c|}{ Length of flag leaf $(\mathrm{cm})$} & \multicolumn{3}{|c|}{ Soil covering by plants $(\%)$} \\
\hline & $\begin{array}{l}\text { without } \\
\text { mulching }\end{array}$ & $\begin{array}{l}\text { mulching } \\
\text { with pine } \\
\text { chips }\end{array}$ & $\begin{array}{l}\text { mulching } \\
\text { with birch } \\
\text { chips }\end{array}$ & $\begin{array}{l}\text { without } \\
\text { mulching }\end{array}$ & $\begin{array}{l}\text { mulching } \\
\text { with pine } \\
\text { chips }\end{array}$ & $\begin{array}{l}\text { mulching } \\
\text { with birch } \\
\text { chips }\end{array}$ & $\begin{array}{l}\text { without } \\
\text { mulching }\end{array}$ & $\begin{array}{l}\text { mulching } \\
\text { with pine } \\
\text { chips }\end{array}$ & $\begin{array}{l}\text { mulching } \\
\text { with birch } \\
\text { chips }\end{array}$ \\
\hline & \multicolumn{9}{|c|}{ Bouteloua gracilis } \\
\hline 2009 & $56.1 b^{*}$ & $48.6 \mathrm{a}$ & $49.3 \mathrm{a}$ & $29.4 \mathrm{~b}$ & $30.1 \mathrm{~b}$ & $26.8 \mathrm{a}$ & $47.8 \mathrm{c}$ & $43.3 \mathrm{~b}$ & $35.3 \mathrm{a}$ \\
\hline 2010 & $64.1 \mathrm{~b}$ & $53.5 \mathrm{a}$ & $46.3 \mathrm{a}$ & $45.0 \mathrm{~b}$ & $43.9 \mathrm{~b}$ & $37.7 \mathrm{a}$ & $93.3 \mathrm{a}$ & $88.3 \mathrm{a}$ & $90.0 \mathrm{a}$ \\
\hline \multirow[t]{2}{*}{2011} & $66.7 \mathrm{~b}$ & $61.1 \mathrm{a}$ & $59.8 \mathrm{a}$ & $42.3 \mathrm{a}$ & $39.6 \mathrm{a}$ & $41.6 \mathrm{a}$ & $83.0 \mathrm{a}$ & $85.5 \mathrm{a}$ & $89.3 \mathrm{a}$ \\
\hline & \multicolumn{9}{|c|}{ Panicum virgatum } \\
\hline 2009 & $128.8 \mathrm{~b}$ & $123.3 \mathrm{~b}$ & $112.8 \mathrm{a}$ & $39.3 \mathrm{~b}$ & $38.4 \mathrm{ab}$ & $36.9 \mathrm{a}$ & $52.2 \mathrm{~b}$ & $42.7 \mathrm{ab}$ & $33.7 \mathrm{a}$ \\
\hline 2010 & $181.9 \mathrm{a}$ & $183.7 \mathrm{a}$ & $175.8 \mathrm{a}$ & $49.2 \mathrm{~b}$ & $46.3 \mathrm{ab}$ & $45.1 \mathrm{a}$ & $100.0 \mathrm{a}$ & $100.0 \mathrm{a}$ & $100.0 \mathrm{a}$ \\
\hline \multirow[t]{2}{*}{2011} & $172.3 \mathrm{a}$ & $174.9 \mathrm{a}$ & $172.8 \mathrm{a}$ & $44.2 \mathrm{a}$ & $44.0 \mathrm{a}$ & $43.6 \mathrm{a}$ & $100.0 \mathrm{a}$ & $100.0 \mathrm{a}$ & $100.0 \mathrm{a}$ \\
\hline & \multicolumn{9}{|c|}{ Pennisetum alopecuroides } \\
\hline 2009 & $86.2 \mathrm{~b}$ & $76.4 \mathrm{a}$ & $71.2 \mathrm{a}$ & $41.1 \mathrm{a}$ & $43.2 \mathrm{a}$ & $46.4 \mathrm{a}$ & $57.5 \mathrm{~b}$ & $43.2 \mathrm{a}$ & $42.3 \mathrm{a}$ \\
\hline 2010 & $125.3 \mathrm{a}$ & $106.6 \mathrm{a}$ & $121.8 \mathrm{a}$ & $65.5 \mathrm{a}$ & $67.8 \mathrm{a}$ & $71.6 \mathrm{a}$ & $100.0 \mathrm{a}$ & $100.0 \mathrm{a}$ & $100.0 \mathrm{a}$ \\
\hline 2011 & $106.8 \mathrm{a}$ & $106.7 \mathrm{a}$ & $108.5 \mathrm{a}$ & $107.5 \mathrm{a}$ & $106.9 \mathrm{a}$ & $122.2 \mathrm{a}$ & $100.0 \mathrm{a}$ & $100.0 \mathrm{a}$ & $100.0 \mathrm{a}$ \\
\hline
\end{tabular}

*Values marked with the same letters in rows do not differ significantly at $p=0.05$ 
of cultivation the adverse effects were shown only by birch chips, which only inhibited the growth of flag leaves. In the third year of cultivation, we did not observe any negative effects of mulching on the growth of plants. Mulching also affected the growth of $P$. alopecuroides, but only in the first year of cultivation. Mulched plants were on average shorter by $12.4 \mathrm{~cm}$ and covered the soil surface to a lesser extent (by 14.8 percentage points). In the second and third year mulching did not influence the growth of plants.

The negative effect of mulching was demonstrated by weaker plant growth and flowering, and the related accumulation of phenolic compounds in the upper soil layer, particularly visible in the first year of cultivation. Although in the second year in the spring, the level of phenolic compounds in soil was higher than a year earlier, plant growth was more balanced and less dependent on mulching. This may indicate greater tolerance to phenolic compounds in older, more mature plants, especially strongly growing species such as $P$. virgatum and $P$. alopecuroides, if only for the reason that their root system penetrates into deeper layers of soil, where phenolic compound levels could be lower. This is confirmed by the results of the indices of growth and flowering in the third year of the study, in which the negative effects of mulching on growth were only occasional - only a lower abundance of flowering was observed. The greater sensitivity of young plants to phytotoxic compounds in the soil was reported by Chalker-Scott (2007), who underlines that the weaker growth of mulched plants was observed in urban greenery areas, usually after their planting. Moreover, many studies have shown negative effects of materials for mulching in laboratory assays conducted on seedlings (Rathinasabapathi et al. 2005).

The results of studies on the influence of different wood materials used as mulches on plant growth are ambiguous, but in many studies it is often not stated from what species of tree the wood material was obtained and whether it was composted. The beneficial effect of wood pallets applied to soil to a depth of $30 \mathrm{~cm}$ in the first year of pecan tree cultivation (Carya illinoinensis) was reported by Smith et al. (2000). Young trees were taller than those growing in the control soil and also had a larger trunk diameter. However, mulching soil with wood chips in the cultivation of cabbages affected neither the spring nor autumn harvest (Guertal and Eduards 1996). Many results indicate, however, the positive effects of wood mulches on plant growth by improving soil properties. Wood mulches may increase the amounts of organic matter and nutrients in the soil and do not change the reaction of the soil (Herms et al. 2002, Broschat 2007, Cregg and Schutzki 2009).

Mulching of the soil also displayed a negative impact on the flowering of ornamental grasses (Tab. 3). In 2009, non-mulched plants of B. gracilis started flowering on $10 \mathrm{July}$, while flowering was

Table 3. The effect of mulching with pine and birch chips on the flowering of ornamental grasses

\begin{tabular}{|c|c|c|c|c|c|c|c|c|c|}
\hline \multirow[b]{2}{*}{ Year } & \multicolumn{3}{|c|}{ Onset of flowering (date) } & \multicolumn{3}{|c|}{$\begin{array}{l}\text { Number of inflorescences } \\
\text { per one plant }\end{array}$} & \multicolumn{3}{|c|}{ Length of inflorescence $(\mathrm{cm})$} \\
\hline & $\begin{array}{l}\text { without } \\
\text { mulching }\end{array}$ & $\begin{array}{l}\text { mulching } \\
\text { with pine } \\
\text { chips }\end{array}$ & $\begin{array}{l}\text { mulching } \\
\text { with birch } \\
\text { chips }\end{array}$ & $\begin{array}{l}\text { without } \\
\text { mulching }\end{array}$ & $\begin{array}{l}\text { mulching } \\
\text { with pine } \\
\text { chips }\end{array}$ & $\begin{array}{l}\text { mulching } \\
\text { with birch } \\
\text { chips }\end{array}$ & $\begin{array}{l}\text { without } \\
\text { mulching }\end{array}$ & $\begin{array}{c}\text { mulching } \\
\text { with pine } \\
\text { chips }\end{array}$ & $\begin{array}{l}\text { mulching } \\
\text { with birch } \\
\text { chips }\end{array}$ \\
\hline & \multicolumn{9}{|c|}{ Bouteloua gracilis } \\
\hline 2009 & July $10^{\text {th }}$ & July $10^{\text {th }}$ & July $21^{\text {st }}$ & $13.1 \mathrm{~b}^{*}$ & $7.4 \mathrm{a}$ & $5.1 \mathrm{a}$ & $43.3 \mathrm{~b}$ & $40.2 \mathrm{ab}$ & $33.5 \mathrm{a}$ \\
\hline 2010 & July $1^{\text {st }}$ & July $2^{\text {nd }}$ & July $2^{\text {nd }}$ & $108.9 \mathrm{~b}$ & $95.6 \mathrm{ab}$ & $83.6 \mathrm{a}$ & $56.7 \mathrm{a}$ & $53.5 \mathrm{a}$ & $49.7 \mathrm{a}$ \\
\hline \multirow[t]{2}{*}{2011} & June $29^{\text {th }}$ & July $1^{\text {st }}$ & July $2^{\text {nd }}$ & $209.3 \mathrm{c}$ & $154.0 \mathrm{a}$ & $167.7 \mathrm{a}$ & $77.8 \mathrm{~b}$ & $66.9 \mathrm{a}$ & $65.1 \mathrm{a}$ \\
\hline & \multicolumn{9}{|c|}{ Panicum virgatum } \\
\hline 2009 & July $18^{\text {th }}$ & July $19^{\text {th }}$ & July $24^{\text {th }}$ & $13.4 \mathrm{~b}$ & $13.3 \mathrm{~b}$ & $8.3 \mathrm{a}$ & $89.1 \mathrm{~b}$ & $83.5 \mathrm{a}$ & $80.8 \mathrm{a}$ \\
\hline 2010 & July $28^{\text {th }}$ & July $22^{\text {nd }}$ & July $21^{\text {st }}$ & $214.8 \mathrm{~b}$ & $208.6 \mathrm{~b}$ & $168.4 \mathrm{a}$ & $180.4 \mathrm{~b}$ & $178.4 \mathrm{~b}$ & $169.3 \mathrm{a}$ \\
\hline \multirow[t]{2}{*}{2011} & July $23^{\text {th }}$ & July $22^{\text {nd }}$ & July $20^{\text {th }}$ & $243.3 \mathrm{~b}$ & $210.1 \mathrm{a}$ & $200.6 \mathrm{a}$ & $183.0 \mathrm{a}$ & $183.1 \mathrm{a}$ & $181.1 \mathrm{a}$ \\
\hline & \multicolumn{9}{|c|}{ Pennisetum alopecuroides } \\
\hline 2009 & Aug. $22^{\text {nd }}$ & Sept. $4^{\text {th }}$ & Sept. $9^{\text {th }}$ & $45.5 \mathrm{~b}$ & $22.1 \mathrm{a}$ & $18.5 \mathrm{a}$ & $92.9 \mathrm{~b}$ & $67.2 \mathrm{a}$ & $77.8 \mathrm{a}$ \\
\hline 2010 & Aug. $9^{\text {th }}$ & Aug. $12^{\text {th }}$ & Aug. $9^{\text {th }}$ & $62.1 \mathrm{~b}$ & $51.6 \mathrm{ab}$ & $43.2 \mathrm{a}$ & $59.3 \mathrm{c}$ & $46.7 \mathrm{~b}$ & $37.6 \mathrm{a}$ \\
\hline 2011 & Aug. $5^{\text {th }}$ & Aug. $6^{\text {th }}$ & Aug. $5^{\text {th }}$ & $88.2 \mathrm{~b}$ & $59.9 \mathrm{ab}$ & $49.2 \mathrm{a}$ & $112.5 \mathrm{a}$ & $121.6 \mathrm{a}$ & $119.1 \mathrm{a}$ \\
\hline
\end{tabular}

*Explanation: see Table 2 
delayed by 11 days under the influence of mulching with birch chips. In subsequent years the onset of flowering was aligned but both types of mulches reduced the number of inflorescences produced. In the first year of cultivation plants mulched with pine chips formed $42.7 \%$ fewer inflorescences, and about $61 \%$ fewer with birch chips compared to nonmulched plants. This effect remained in subsequent years, although showing a downward trend. In the second year of cultivation plants mulched with the birch chips produced 23\% fewer inflorescences than non-mulched plants, while in the third year of cultivation plants mulched with pine chips formed $26.4 \%$ fewer inflorescences, and 19.9\% fewer than non-mulched plants. Mulching also influenced the growth of flowering culms. In the first year of growth, a negative impact was observed only for birch chips; the plants mulched with them had shorter culms than non-mulched plants by $9.8 \mathrm{~cm}$, i.e. by $22.6 \%$, while in the third year of cultivation mulching limited their growth by an average of about $15 \%$. In the second year of cultivation significant differences in the length of flowering culms between mulched and non-mulched plants were not observed. The onset of $P$. virgatum flowering of control plants began on 18 July in 2009 . Plants mulched with pine chips blossomed at approximately the same time, while plants mulched with birch chips blossomed 5-6 days later than plants from the other objects. In the subsequent years, the cultivated plants came into flower at a similar time regardless of mulching. We also observed a negative impact of the wood chips on the number of inflorescence culms of $P$. virgatum and their length. In the first and second year the plants mulched with birch chips produced the fewest inflorescences, about 37.6-38.1\% and $19.3-21.6 \%$ fewer, respectively, than the control plants. In the third year the non-mulched plants formed on average 243 inflorescence culms, and the mulched ones $13.6-17.6 \%$ fewer. Mulching with chips demonstrated a negative effect on the length of inflorescence culms in the first year of cultivation, while this effect was only felt under the influence of birch chips in the second year. In the cultivation of $P$. alopecuroides the flowering of non-mulched plants began on 22 August in 2009. Pine chips delayed the flowering by 13 days, and birch chips by 17 days. In the following years, the cultivation of the beginning of flowering was aligned. In the first year mulching limited the number of inflorescences by more than $50 \%$. In the following years, only the plants mulched with birch chips bloomed less abundantly than the non-mulched plants - in the second year by $30.4 \%$ and in the third year by $44.2 \%$. Mulching P. alopecuroides also caused the growth inhibition of flowering culms in the first two years. In the first year both types of wood chips to a similar extent resulted in a reduction of the growth of culms, and in the second year the plants mulched with birch chips had shorter by $9.1 \mathrm{~cm}$ culms than those mulched with pine chips. A positive influence of mulching with wood chips on soil moisture in the orchard after planting apple trees (Malus domestica 'Gala Must') was reported by Treder et al. (2004). Consequently mulching made the apple trees grow more strongly, but like the grasses in our experiment they bloomed less abundantly than non-mulched plants. Cregg and Schutzki (2009) also demonstrated that mulching with wood chips from chopped pallets increased soil moisture and positively affected the intensity of the photosynthesis of plants used in urban green areas.

The negative effect of a mulch can result from various causes, including due to the biological sorption of nitrogen. The mineralization of organic mulch distinguished by a high ratio of $\mathrm{C}: \mathrm{N}$ can lead to sorption of nitrogen from the top layer of soil. Weakening in plant growth can be the result of this sorption. However, the results of many years research indicate that mulch from straw may have a beneficial effect on the content of mineral nitrogen in the soil (Bielińska and Głowacka 2004). Moreover the annual comfortable fertilizing grasses in our own experience, effectively prevented the deficiency of nutrients. Surely it would be important to perform the next experiment in order to clarify the progress in mineralization of mulches from pine and birch wood chips.

Our experiment showed that the ornamental grasses mulched with birch chips grew and bloomed less than plants mulched with pine chips not only in the first year, but also in the second one, when there were no significant differences in the accumulation of phenolic compounds between soil mulched with pine and birch chips. These results suggest the secretion of other phytotoxic substances from birch chips. According to Krasutsky (2006), the bark of Betula pendula contains large amounts of medium polar triterpenes, among which the largest part is betulin (78.1\%), with lower amounts of betulinic acid (4.3\%), and lupeol (7.9\%). The phytotoxicity of these compounds has been shown in numerous biological assays (Macías et al. 1994). Pine wood contains a lot of volatile monoterpenes, mainly $\alpha$-pinene, which quickly diffuses into the atmosphere (Johansson and Rasmuson 1998). The 
results of a study by Foshee et al. (1996) showed the positive result of the use of mulches from pine wood to grow woody plants. They applied pine nuggets and pine straw, which had a positive impact on growth of young pecan trees grown in containers. The work of Jackson et al. (2008) demonstrated that pine bark and wood (crushed, non-composted, with the addition of fertilizers) can be used as components of substrates for growing plants.

\section{CONCLUSIONS}

Mulching with pine and birch chips resulted in an increase of the content of phenolic compounds in the soil. The phenolic compounds were secreted throughout the growing period, which resulted in their greatest accumulation in autumn. In the first year of cultivation more phenolic compounds were released from pine chips than from birch chips. Mulching with chips demonstrated a negative impact on the growth and flowering of ornamental grasses, especially in the first year of cultivation. Compared to the pine chips birch chips restricted $P$. virgatum height to the greater extent, and the length of flag leaves and soil coverage by leafy blades of $B$. gracilis and $P$. virgatum, and negatively affected the characteristics associated with flowering for all of the examined species of ornamental grasses.

Pine chips can be used for mulching ornamental grasses. The deterioration of decorative qualities of the examined plant species (delayed flowering and a significant reduction in the number of inflorescences) disqualifies birch chips as a mulch in the cultivation of ornamental grasses. However, in spite of the above, birch chips can be used as material for mulches mixed with various components. However, this requires further research because the decaying wood chips can release into soil other toxic chemicals than phenolic compounds and as the material with a wide $\mathrm{C}: \mathrm{N}$ ratio can cause a biological sorption of nitrogen.

\section{FUNDING}

This work was financially supported by Ministry of Science and Higher Education as part of the research to sustain the research potential of the Department of Ornamental Plants at the University of Life Sciences in Poznań.

\section{AUTHOR CONTRIBUTIONS}

M.H. - concept of the study; M.H., B.P. - field research; M.H. - data analyses; M.H., B.P. - writing of the manuscript; M.H., B.P. - comments on the manuscript.

\section{CONFLICT OF INTEREST}

Authors declare no conflict of interest.

\section{REFERENCES}

Bantle A., Borken W., Ellerbrock R.H., Schulze E.D., Weisser W.W., Matzner E., 2014. Quantity and quality of dissolved organic carbon released from coarse woody debris of different tree species in the early phase of decomposition. Forest Ecol. Manag. 329: 287-294.

BielińsKa E.J., GŁowackA A., 2004. Zawartość mineralnych form azotu w glebie sadu jabłoniowego w zależności od metod jej pielęgnacji [The mineral nitrogen content in the soil of apple orchard in relation to the soil treatment]. Acta Sci. Pol., Hortorum Cultus 3(2): 131-145.

BRoschat T.K., 2007. Effect of mulch type and fertilizer placement on weed growth and soil $\mathrm{pH}$ and nutrient content. HortTechnology 17(2): 174-177.

Chalker-ScotT L., 2007. Impact of mulches in landscape plants and the environment - a review. J. Environ. Hort. 25(4): 239-249.

Cregg B.M., Schutzki R., 2009. Weed control and organic mulches a affect physiology and growth of landscape shrubs. HortScience 44(5): 1419-1424.

Duryea M.L., 2000. Landscape mulches: What are the choices in Florida. FOR 80: http://edis.ifas.ufl.edu.

Foshee W.G., Goff W.D., Tilt K.M., Williams J.D., 1996. Organic mulches increase growth of young pecan trees. HortScience 31(5): 811-812.

Guertal E.A., Eduards J.H., 1996. Organic mulch and nitrogen affect spring and fall collard yields. HortScience 31(5): 823-826.

Henschke M., 2013. Znaczenie traw ozdobnych w terenach zieleni [The importance of ornamental grasses in green areas]. In: Ogrodnictwo ozdobne sektorem gospodarki narodowej. J. Rabiza-Świder and E. Skutnik E. (eds), SGGW, Warszawa: 119-123.

Henschke M., 2014. Trawy ozdobne - nowa grupa roślin do terenów zieleni miejskiej [Ornamental grasses - a new group of plants for urban greenery]. In: Kierunki zmian terenów zieleni w miastach. M. Kosmala (ed.), Toruń, Poland: 377-398.

Henschke M., Jerzy M., 2006. Wpływ ściółkowania korą sosnową na wzrost i kwitnienie okrywowych odmian róż [The effect of mulching with pine bark on growth and flowering ground cover roses]. Zesz. Probl. Post. Nauk Roln. 510(1): 185-194.

Henschke M., Jerzy M., Cieciora M., 2008. Wpływ ściółkowania korą sosnową na wzrost i kwitnienie okrywowych odmian róż $\mathrm{w}$ czwartym i piątym roku uprawy [The effect of pine bark mulching on growth and flowering of ground cover roses in fourth and 
fifth years of growth]. Zesz. Probl. Post. Nauk Roln. 525: 153-161.

Herms D.A., Lloyd J.E., Stinner B.R., 2002. Effect of organic mulches and fertilization on soil microbial activity nutrient availability and growth of river birch. In: Composting and Compost Utilization. F.C. Michel, R. Rynk, and H.A.J. Hoitink (eds), The JG Press Inc., Emmaus, PA.

JACKson B.E., Wright R.D., Browder J.F., Harris J.R., Niemier A.X., 2008. Effect of fertilizer rate on growth of azalea and holly in pine bark and pine tree substrates. HortScience 3(5): 1561-1563.

JOHANSSON A., RASMUSON A. 1998. the release of monoterpenes during convective drying of wood chips. Dry. Technol. 16(7): 1395-1428.

Krasutsky P.A., 2006. Birch bark research and development. Nat. Prod. Rep. (23): 919-942.

Macías FA, Simonet AM, Esteban MD. 1994. Potential allelopathic lupane triterpenes from bioactive fractions of Melilotus messanensis. Phytochemistry 36: 1369-1379.

Politycka B., Wóscik-Wojtkowiak D., 1984. Substancje fitotoksyczne w podłożach wielokrotnie użytkowanych w uprawie szklarniowej ogórka i pomidora. I. Związki fenolowe i substancje o aktywności auksynowej [Phytotoxic substances in the substrates many times used in greenhouse cultivation of cucumber and tomato. I. Phenolic compounds and substances with auxin activity]. Biul. Warzyw. 27: 585-597.

Rathinasabapathi B., Ferguson J., Gal M., 2005. Evaluation of allelopathic potential of wood chips for weed suppression in horticultural production system. HortScience 40(3): 711-713.

Reigosa M.J., Pedrol M., 2002. Allelopathy: from molecules to ecosystems. Science Publishers, Enfield, New Hampshire, USA: 385-389.

Sánchez-Moreiraz A.M., Weiss O.A., Reigosa-Roger M.J., 2015. Allelopathic evidence in Poaceae. The Bot. Rev. 69(3): 300-319.

Singleton, V. L., Orthofer, R., Lamuela-Raventós, Rosa M., 1999. Analysis of total phenols and other oxidation substrates and antioxidants by means of Folin-Ciocalteu reagent. Method. Enzym. 299: 152178.

Smith M.W., Carroll B.L., Cheary B.S., 2000. Mulch improves pecan tree growth during orchard establishment. HortScience 35(2): 192-195.

Treder W., Klamkowski K., Mika A., Wójcik P., 2004. Response of young apple trees to different orchard floor management system. J. Fruit Ornam. Plant Res., Special ed. 12: 113-123.

Received February 3, 2016; accepted November 8, 2016 